\title{
Vamp $^{\mathrm{TM}}$ Coverage Area for Personnel Protection (U)
}

by

C. A. Roach

Westinghouse Savannah River Company

Savannah River Site

Aiken, South Carolina 29808

J. R. Cantrell

Westinghouse Savannah River $C O$.

SC USA

P. d'Entremont

W. F. Bates

R. L Salizzoni

DOE Contract No. DE-AC09-89SR18035

This paper was prepared in connection with work done under the above contract number with the U.S.

Department of Energy. By acceptance of this paper, the publisher and/or recipient acknowledges the U.S. Government's right to retain a nonexclusive, royalty-free license in and to any copyright covering this paper, along with the right to reproduce and to authorize others to reproduce all or part of the copyrighted paper. 


\section{DISCLATMER}

This report was prepared as an account of work sponsored by an agency of the United States Government. Neither the United States Government nor any agency thereof, nor any of their employees, makes any warranty, express or implied, or assumes any legal liability or responsibility for the accuracy, completeness, or usefulness of any information, apparatus, product, or process disclosed, or represents that its use would not infringe privately owned rights. Reference herein to any specific commercial product, process, or service by trade name, trademark, manufacturer, or otherwise does not necessarily constitute or imply its endorsement, recommendation, or favoring by the United States Government or any agency thereof. The views and opinions of authors expressed herein do not necessarily state or reflect those of the United States Government or any agency thereof.

This report has been reproduced directly from the best available copy.

Available to DOE and DOE contractors from the Office of Scientific and Technical Information, P.O. Box 62, Oak Ridge, TN 37831; prices available from (615) 576-8401.

Available to the public from the National Technical Information Service, U.S. Department of Commerce, 5285 Port Royal Road, Springfield, VA 22161. 


\section{DISCLAIMER}

Portions of this document may be illegible in electronic image products. Images are produced from the best available original document. 
G. T. Wright, 703-H

T. L. Lex, 719-4A

J. W. French, 703-H

$\mathrm{H}$. Handfinger, 704-56

T. M. Monahon, 703-H

B. G. Croley, 241-119H

V. G. Dickert, 703-H

C. A. Polson, 707-H

G. Davis, $241-100 \mathrm{~F}$

M. D. Johnson, 704-56H

R. L. Salizzoni, 707-H

W. G. Clark, 241-119H

J. E. Marra, 703-H

E. Saldivar, 703-H

B. L. Lewis, 703-8C

I. B. Guilherme, 703-H

T. D. Phillips, 703-H

G. D Thaxton, $241-119 \mathrm{H}$

W. F. Bates, 703-H

M. A. Ceravolo, 707-H(2)

A. W. Wiggins, $241-84 \mathrm{H}$

B. R. Hess, 241-102F(2)

S. A. Saunders, $241-102 \mathrm{H}$

T. L. Ortner, $241-152 \mathrm{H}$

G. McDougal, 242-119H

T. B. Caldwell, 703-6C

W. B. Renfro, 703-H

S. G. Brown, 707-H

D. F. McLane, 707-H

K. A. Hauer, 241-100F

L. G. Lawson, $241-154 \mathrm{H}$

T. R. Jones, $707-\mathrm{H}$

G. Tunno, 703-H

K. H. Rosenberger, 735-11A

R. S. Howell, 735-11A

J. R. Cantrell, 703-H

P. d'Entremont, 703-H

C. A. Roach, 703-H
W.A. Lanham, 707-H

F. D. Vick, 707-H

J. W. Smith, 705-1C

W.A. Morrison, 241-100F

B. Vann, 703-H

HLWE File Room, 703-H

File code:401.9.7

Records Mngt., 773-52A, (4cc) 
HIGH LEVEL WASTE ENGINEERING

SUPPORT SYSTEMS ENGINEERING

WSRC-TR-95-0004

REVISION: 0

KEYWORDS:

VAMP

Tank Farms

RENTENTION:

Permanent

CLASSIFICATION: (U)

Does Not Contain UNCI

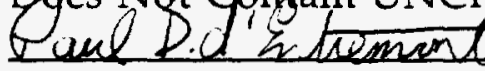

$A D C / R O$

VAMPTM COVERAGE AREA FOR

PERSONNEL PROTECTION (U)

January 3, 1995

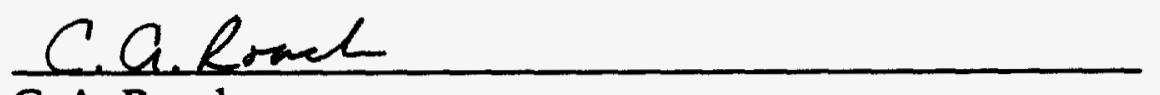

C. A. Roach

Author

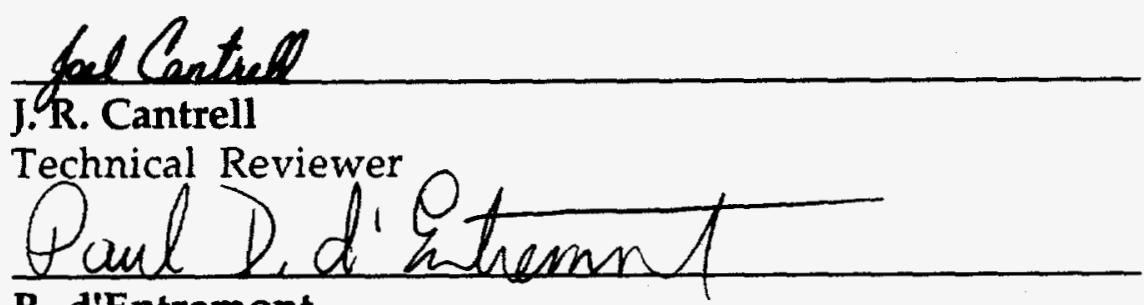

P. d'Entremont

Technical Reviewer

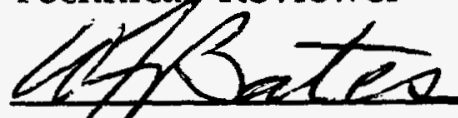

W. F. Bates

Manager, Support Systems Engineering

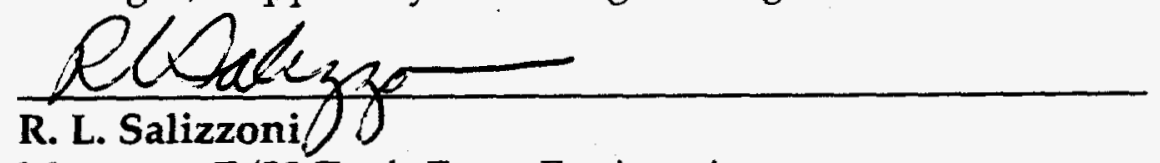

Manager, F/H Tank Farm Engineering $\frac{1 / 3 / 95}{\text { Date }}$

$1 / 5 / 95$

Date
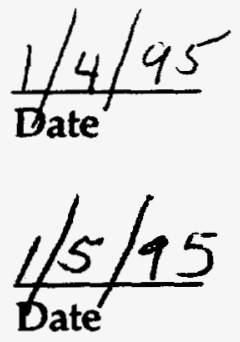

$1 / 9 / 95$

Date 
WSRC-TR-95-0004

January 3, 1995

Page 2 of 11

\section{INTRODUCTION}

The VAMP ${ }^{\mathrm{TM}}$ Area Radiation Monitors, in addition to functioning as radiation monitors for process upsets, as required by the OSR, provide monitoring in order to detect and alarm increasing radiation for the purpose of controlling exposure of personnel to radiation.

Operational Safety Requirements (DPW-86-103) requires that area radiation monitors be provided in the vicinity of all waste tanks to ensure safe operation. The proposed Operational Safety Requirements (WSRC RP-92-1044) establish the minimum number of area radiation monitors for operation and the maximum distance from the monitored location for the purpose of detecting potential leaks .

Article 553 of the DOE Radiological Control Manual indicates that area radiation monitors should be installed in frequently occupied locations with the potential for unexpected increases in dose rates and in remote locations where there is a need for local indication of dose rates prior to personnel entering remote locations.

Currently, there is no technical basis established for the use of the VAMP for limiting exposure of personnel in the F or $\mathrm{H}$ Tank Farms. This report will establish that basis, map current area radiation monitor locations and provide a list of recommended actions to correct situations where VAMP coverage may be inadequate in limiting exposure of personnel. In addition, the current reporting criteria described in the 9B5 Manual will be addressed in this report.

\section{SUMMARY}

The current location of area radiation monitors provide the coverage required by the OSR criteria and, with few exceptions, these monitors also provide the necessary coverage for personnel protection. The exceptions to the coverage for personnel protection are listed below along with the proposed action to bring the facility into compliance with the DOE Radiological Manual. The exceptions are based upon the assumptions, which HLWE believes are conservative, used to develop the coverage maps generated by Health Physics Technology (HPT).

No change to the 9B5 Manual reporting criteria relating to area radiation monitors is required.

No change to transfer procedures to provide additional VAMP coverage for personnel protection is required for a source term that is greater than that assumed in this report.

It is expected that this Technical Report will provide the basis for future assessment when changes to the facility are initiated. 
vroKL-TR-95-0004

January 3, 1995

Page 3 of 11

\section{DISCUSSION}

Health Physics Technology performed an evaluation of the area radiation monitor coverage area in the SRS High Level Waste Tank Farms (Ref. 1). This evaluation used a dose of $300 \mathrm{mrem}$ delivered in a 10 hour time period ( $30 \mathrm{mrem} / \mathrm{hr}$ at 10 feet) as a basis for determining the coverage. This rate was chosen by HPT and High Level Waste Engineering (HLWE) because $300 \mathrm{mrem} / \mathrm{month}$ is the SRS Administrative Control Guide limit. Included in the selection is the knowledge that weekly surveys of routinely occupied areas are performed by RCO per Procedure 147 of Manual 5Q1.2. Further, a daily/shift operational check of the VAMP is performed by Radiological Controls Operations (RCO) per Procedure 103A of Manual 5Q1.7 and by Operations per their Roundsheets.

The choice of spill type and amount was based upon selecting a waste concentration that would yield a high dose rate but have the smallest spill size. This small amount would be more difficult to detect by observation at some distance. A distance for the limit of observation was chosen as 10 feet. This means that it is assumed that a leak within ten (10) feet of a worker will be observed prompting a responsive action.

The selection of high heat supernate with a Cesium 137 content of $9.6 \mathrm{E}+00 \mathrm{Ci} / \mathrm{gal}$ (Reference 2, Table 3-3) in a quantity of 0.06 gallons (about 8 ounces) provides a dose rate of $30 \mathrm{mrem} / \mathrm{hr}$ at 10 feet. This results in a single detection radius of 42 feet for those VAMPS located where the background is $0-5 \mathrm{mrem} / \mathrm{hr}, 34$ feet for a background of $6-10 \mathrm{mrem} / \mathrm{hr}$, and 30 feet for a background of $11-20 \mathrm{mrem} / \mathrm{hr}$ (Graph \#1). The difference in radii versus background occurs since the VAMP nominal setpoints are:

background $+2 \mathrm{mrem} / \mathrm{hr}$ for a background of $0-5 \mathrm{mrem} / \mathrm{hr}$, background $+3 \mathrm{mrem}$ for a background of $6-10 \mathrm{mrem} / \mathrm{hr}$, and background $+4 \mathrm{mrem} / \mathrm{hr}$ for a background of $11-20 \mathrm{mrem} / \mathrm{hr}$.

The source term chosen is an "average typical" value. It is not intended to be a limiting value for a waste concentration. A waste with a higher source term would initiate a VAMP alarm before 0.06 gallons were spilled with no significant change in the accumulated dose, while a lower source term would require a larger volume than the volume chosen.

Figures 1 through 10 of Ref. 1, attached, denote VAMP locations and were compiled from engineering drawings, the site map, and a walkdown of the facilities by HPT with facility personnel. Potential increased radiation sites outside the coverage areas such as valve houses, pumps, jets, etc., were identified during the evaluation and depicted on the figures listed below. Some tank top sites are identified using the riser identification.

Figures 11 through 20 of Ref. 1, attached, include the addition of the VAMP coverage areas to the maps and reflect the effect of shielding by structures/components. Using 
$\because 0 \times-1, j 004$

January 3, 1995

Page 4 of 11

these figures, a second series of walkdowns by facility engineering personnel identified additional potential leak sites that are outside the defined coverage areas. These additional sites were added to Table 1 . With few exceptions, the background is $\leq 5 \mathrm{mrem} / \mathrm{hr}$ at current installations. Therefore, a 42 foot radius was used to define the coverage area for the purpose of this tabulation.

The probable sites for process upsets outside defined coverage, including those identified during facility engineering walkdowns, are listed in Table 1. Operational sketches (138-8 series) were used to identify the equipment located on the tank tops.

The current 9B5 Manual reporting criteria permits credit to be taken for a second area radiation monitor that is installed within five (5) feet of a degraded monitor.

Using the relationship of dose rate versus distance for a point source and ten versus five feet for the calculation:

$$
\mathrm{R}_{2}=\mathrm{R}_{1} /\left(\mathrm{d}_{2} / \mathrm{d}_{1}\right)^{2}
$$

If the dose rate at 52 feet is $2 \mathrm{mrem} / \mathrm{hr}$ above background then the rate at 42 feet is approximately $3 \mathrm{mrem} / \mathrm{hr}$. This ratio of $1.5 \mathrm{can}$ then be applied to Graph 1 such that the rate at 10 feet is approximately $45 \mathrm{mrem} / \mathrm{hr}$ for a rate of $2 \mathrm{mrem} / \mathrm{hr}$ at 52 feet .

Although this increased rate would result in a higher accumulated dose with the assumptions presented in this document, HLWE and RCO conclude that this criteria is reasonable and justified based upon the following:

1. The risk associated with personnel exposure is low since once an area radiation monitor is determined to be inoperable, actions are procedurally initiated to either permanently replace the monitor, manually monitor, or install a portable monitor at that location. This minimizes the window of vulnerability that a particular area is without monitoring capability. If responding to an alarm condition, actions are initiated to stop transfers in the vicinity of the alarming monitor along with initiation of area surveys to determine existing conditions.

2. The assumption that personnel will remain within ten (10) feet of the postulated spill for a ten (10) hour period is considered conservative.

Once the following actions have been completed, it is the judgment of HLWE that the installed area radiation monitors will provide the monitoring intended by article 553 of the DOE Radiological Manual. 
WSKL-1K-39-UNu4

January 3, 1995

Page 5 of 11

\section{ACTIONS}

Plant Modification Travelers (U-PMT-H-01266 and F-00569) have been issued for facility approval to install a VAMP(s) in the vicinity of the following components:

1. Tank 49 Valve Box

2. Tank 7 Transfer Line (riser 4) - Although there is no pump currently installed at riser 4, it is understood that Project S2081 will install a pump to be used for Waste Removal.

3. Tank $48 /$ Process Building Transfer Lines.

As an interim measure, portable VAMPS will be installed at these locations. These PMTs and associated Work Requests will be prioritized and categorized by facility Work Scope Review Teams (WSRT) to determine priority and schedule.

\section{REFERENCES:}

1. Rosenberger, K. H., ESH-HPT-94-0154, Evaluation of Coverage Areas of Radiation Monitors In The SRS High Level Waste Tank Farms (U), July 21, 1994.

2. WSRC-RP-92-964, Iustification For Continued Operation (U), April 1993.

3. W. C. Perkins and C. R. Lux, WSRC-TR-91-562, Releases From The Cooling-Water System In The Waste Tank Farm (U), January 27, 1992.

4. HLW Procedure 241-FH-156 T-R, Ietting From Waste Tank Annulus To A Waste Tank (U).

5. DPW-86-103, Operational Safety Requirements for Waste Management Operations, Rev. 1, February 23, 1989.

6. Rosenberger, K. H., ESH-HPT-93-0277, Waste Removal and Extended Sludge Processing, S2081 - Determination of Waste Spill Volumes to Alarm Gamma Monitors (U) May 28, 1994.

7. DPSTSA-200-10 SUP 18, IIP Safety Analysis Report Table 2.7 Spent Wash Water (ITP).

8. Pike, J. A., HLW-HLE-94-0958, Tank Chemistry Report, October 1994 (U), November 18, 1994.

9. WSRC-RP-92-1044, Operational Safety Requirements, F- and H-Area High-Level Radioactive Waste Tank Farms (U). 
WSRC-TK

January 3, 1995

Page 6 of 11

TABLE 1

POTENTIAL RADIATION SITES (OUTSIDE DEFINED COVERAGE)

\begin{tabular}{|c|c|c|c|c|}
\hline FIG & LOCATION & ITEM & NOTE & ACTION \\
\hline$\overline{11}$ & TANK 35 & HVAC & 1 & NONE \\
\hline 11 & TANK 36 & HVAC & 1 & NONE \\
\hline 11 & TANK 36 & VALVE HOUSE & 5 & NONE \\
\hline 11 & TANK 37 & HVAC & 1 & NONE \\
\hline 11 & TANK 37 & VALVE HOUSE & 5 & NONE \\
\hline 12 & TANK 23 & HVAC & 1 & NONE \\
\hline 12 & TANK 24 & TELESCOPING XFER JET & 7 & NONE \\
\hline$\overline{12}$ & TANK 21 & S. RISER (TRANSFER PUMP) & 10 & $\overline{N O N E}$ \\
\hline$\overline{12}$ & TANK 21 & SE. RISER (SLURRY PUMP) & 10 & $\overline{\text { NONE }}$ \\
\hline 12 & TANK 21 & HVAC & 1 & NONE \\
\hline$\overline{12}$ & TANK 22 & S. RISER (TRANSFER PUMP) & 10 & NONE \\
\hline$\overline{12}$ & TANK 22 & SE. RISER (SLURRY PUMP) & 10 & NONE \\
\hline$\overline{12}$ & TANK 22 & HVAC & 1 & NONE \\
\hline$\overline{12}$ & TANK 22 & SW. RISER (SLURRY PUMP) & 10 & NONE \\
\hline$\overline{12}$ & TANK 22 & VALVE BOX & 10 & NONE \\
\hline$\overline{12}$ & TANK 24 & S. RISER (SLURRY PUMP) & 8 & NONE \\
\hline 12 & TANK 24 & HVAC & 1 & NONE \\
\hline 12 & CTS & HVAC & 1 & NONE \\
\hline 12 & TANK 32 & A1 RISER (ANNULUS JET) & 4 & NONE \\
\hline 12 & TANK 32 & HVAC & 1 & NONE \\
\hline 12 & TANK 29 & HVAC & 1 & NONE \\
\hline 13 & TANK 9 & RISER 1 (TC WELL) & 6 & NONE \\
\hline 13 & TANK 9 & RISER 8 (PURGE INLET) & 6 & NONE \\
\hline 13 & TANK 9 & VALVE HOUSE & 2 & NONE \\
\hline 13 & TANK 10 & RISER 1 (SPRAY CHAMBER) & 6 & NONE \\
\hline$\overline{13}$ & TANK 10 & RISER 8 (SPRAY CHAMBER) & 6 & NONE \\
\hline$\overline{13}$ & TANK 10 & VALVE HOUSE & $\overline{2}$ & NONE \\
\hline$\overline{13}$ & TANK 11 & RISER 1 (SPRAY CHAMBER) & 6 & NONE \\
\hline$\overline{13}$ & TANK 11 & RISER 7 (BLANKED) & 6 & NONE \\
\hline$\overline{13}$ & TANK 11 & VALVE HOUSE & 2 & NONE \\
\hline 13 & TANK 12 & RISER 1 (SPRAY CHAMBER) & $\overline{6}$ & NONE \\
\hline 13 & TANK 12 & RISER 8 (SPRAY CHAMBER) & 6 & NONE \\
\hline 13 & TANK 12 & VALVE HOUSE & 2 & NONE \\
\hline 13 & TANK 11 & HVAC & 1 & NONE \\
\hline & & & & \\
\hline
\end{tabular}


WSRC-TR-95- 0004

January 3, 1995

Page 7 of 11

TABLE 1 (cont.)

\begin{tabular}{|l|l|l|c|l|}
\hline FIG & LOCATION & \multicolumn{1}{|c|}{ ITEM } & NOTE & ACTION \\
\hline 13 & CATCH TK & GANG VALVES & 11 & NONE \\
\hline 13 & TANK 13 & VALVE HOUSE (PARTIAL) & 5 & NONE \\
\hline 13 & TANK 14 & HVAC (PARTIAL) & 1 & NONE \\
\hline 13 & TANK 14 & VALVE HOUSE & 5 & NONE \\
\hline 13 & TANK 15 & RISER 6 (INSPECTION PORT) & 2 & NONE \\
\hline 13 & TANK 15 & RISER 8 (SPRAY CHAMBER) & 6 & NONE \\
\hline 13 & TANK 15 & VALVE HOUSE & 5 & NONE \\
\hline 13 & TANK 16 & VALVE HOUSE & 5 & NONE \\
\hline 14 & TANK 49 & VALVE BOX & & add vamp \\
\hline 14 & TANK 48 & TK 48 / PROCESS BLDG XFER LINES & & add Vamp \\
\hline 14 & PP 5 \& 6 & HVAC & 1 & NONE \\
\hline 14 & TANK 38 & HVAC & 1 & NONE \\
\hline 14 & TANK 39 & HVAC & 1 & NONE \\
\hline 14 & TANK 40 & HVAC & 1 & NONE \\
\hline 14 & TANK 41 & HVAC & 1 & NONE \\
\hline 14 & TANK 42 & HVAC & 1 & NONE \\
\hline 14 & TANK 43 & HVAC & 1 & NONE \\
\hline 14 & TANK 48 & HVAC & 1 & NONE \\
\hline 14 & TANK 49 & HVAC & 1 & NONE \\
\hline 14 & TANK 50 & HVAC & 1 & NONE \\
\hline 14 & TANK 51 & HVAC & 1 & NONE \\
\hline 16 & TANK 1 & RISER 1 (SLURRY PUMP) & 9 & NONE \\
\hline 16 & TANK 1 & VALVE HOUSE & 2 & NONE \\
\hline 16 & TANK 2 & RISER 1 (SLURRY PUMP) & 9 & NONE \\
\hline 16 & TANK 2 & RISER 2 (ANNULUS JET INLET) & 4 & NONE \\
\hline 16 & TANK 2 & N. RISER (ANNULUS JET) & 4 & NONE \\
\hline 16 & TANK 2 & VALVE HOUSE & 2 & NONE \\
\hline 16 & TANK 3 & RISER 1 (SLURRY PUMP) & 9 & NONE \\
\hline 16 & TANK 3 & RISER 2 (ANNULUS JET INLET) & 4 & NONE \\
\hline 16 & TANK 3 & N. RISER (ANNULUS JET) & 4 & NONE \\
\hline 16 & TANK 3 & VALVE HOUSE & 2 & NONE \\
\hline 16 & TANK 4 & RISER 1 (SLURRY PUMP) & 9 & NONE \\
\hline 16 & TANK 4 & S. RISER (ANNULUS JET) & 4 & NONE \\
\hline 16 & TANK 4 & VALVE HOUSE & 2 & NONE \\
\hline 16 & TANK 5 & RISER 1 (SLURRY PUMP) & 9 & NONE \\
\hline 16 & TANK 5 & RISER 2 (ANNULUS JET INLET) & 4 & NONE \\
\hline & & & \\
\hline
\end{tabular}


WSRC-TR-95-0004

January 3, 1995

Page 8 of 11

TABLE 1 (cont.)

\begin{tabular}{|c|c|c|c|c|}
\hline FIG & LOCATION & ITEM & $\overline{N O T E}$ & ACTION \\
\hline 16 & TANK 5 & N. RISER (ANNULUS JET) & 4 & NONE \\
\hline 16 & TANK 5 & VALVE HOUSE & 2 & NONE \\
\hline$\overline{16}$ & TANK 6 & RISER 1 (SLURRY PUMP) & 9 & NONE \\
\hline$\overline{16}$ & TANK 6 & VALVE HOUSE & 2 & NONE \\
\hline$\overline{16}$ & TANK 7 & RISER 1 (NOT OBSERVED @ TK TOP) & 3 & NONE \\
\hline$\overline{16}$ & TANK 7 & TRANSFER LINE & & add vamp \\
\hline 16 & TANK 7 & VALVE HOUSE & 2 & NONE \\
\hline 16 & TANK 8 & RISER 1 (SLURRY PUMP) & $\overline{9}$ & NONE \\
\hline 16 & TANK 8 & RISER 2 (INSPECTION PORT) & $\overline{6}$ & NONE \\
\hline 16 & TANK 8 & N. RISER (ANNULUS JET) & $\overline{4}$ & NONE \\
\hline 16 & TANK 8 & VALVE HOUSE & 2 & NONE \\
\hline 17 & TANK 25 & HVAC & 1 & NONE \\
\hline$\overline{17}$ & TANK 26 & HVAC & 1 & NONE \\
\hline 17 & TANK 27 & HVAC & 1 & NONE \\
\hline 17 & TANK 28 & HVAC & $\overline{1}$ & NONE \\
\hline 17 & FDB-4 & $\overline{\text { HVAC }}$ & $\overline{1}$ & NONE \\
\hline 17 & TANK 44 & $\overline{\text { HVAC }}$ & $\overline{1}$ & NONE \\
\hline 17 & TANK 45 & $\overline{\text { HVAC }}$ & $\overline{1}$ & NONE \\
\hline 17 & TANK 46 & $\overline{\text { HVAC }}$ & 1 & NONE \\
\hline 17 & TANK 47 & HVAC & $\overline{1}$ & NONE \\
\hline 17 & EVAP & $\overline{\text { HVAC }}$ & $T$ & NONE \\
\hline 18 & TANK 18 & NW RISER (SLURRY PUMP) & 8 & $\overline{\text { NONE }}$ \\
\hline$\overline{18}$ & TANK 18 & NE RISER (TRANSFER PUMP) & 8 & NONE \\
\hline 18 & TANK 18 & HVAC & 1 & NONE \\
\hline$\overline{18}$ & CTS & HVAC & $\overline{1}$ & NONE \\
\hline$\overline{18}$ & TANK 19 & HVAC & $\overline{1}$ & $\overline{\mathrm{NONE}}$ \\
\hline 18 & TANK 20 & $\overline{\text { HVAC }}$ & 1 & NONE \\
\hline 19 & FDB-2 & HVAC & $\overline{1}$ & NONE \\
\hline 19 & TANK 33 & RISER A4 (ANNULUS JET) & 4 & NONE \\
\hline$\overline{19}$ & TANK 33 & HVAC & 1 & NONE \\
\hline 19 & $\overline{\text { TANK } 34}$ & RISER A4 (ANNULUS JET) & 4 & NONE \\
\hline 19 & TANK 34 & HVAC & 1 & NONE \\
\hline & & & & \\
\hline
\end{tabular}

* background $10 \mathrm{mrem} / \mathrm{hr}$ thus coverage radius of 34 feet 


\section{TABLE 1 NOTES:}

1. HVAC structure is not required to be provided with continuous area radiation monitoring since the structure is not frequently occupied thus there is no requirement for continuous radiation monitoring.

2. No credible event could be postulated at this site which would cause an unexpected increase in dose rate. The siphoning of waste into the Cooling Water System is not considered credible for tanks 1 through 12 due to their elevation (Reference 3).

3. Although shown on operational sketches, no riser is observable at this location.

4. Jetting from a waste tank annulus requires establishing monitoring for radiation prior to and during the transfer (Reference 4). Permanent monitoring at these locations is not required.

5. No credible event could be postulated at this site which would cause an unexpected increase in dose rate, since a siphon mitigation program is required by reference 4 to prevent the occurrence of the postulated siphon event described in Reference 3.

6. No credible event could be postulated at this site which would cause an unexpected increase in dose rate. Maintenance activities will have appropriate $\mathrm{RCO} / \mathrm{RWP}$ monitoring requirements.

7. Based upon the chemical analysis given in the October 1994 Tank Chemistry Report (Ref. 8), the gamma activity of the Tank 24 supernate was determined to be $2.07 \mathrm{E}+07 \mathrm{~d} / \mathrm{m} / \mathrm{ml}$. This converts to a concentration of $3.5 \mathrm{E}-02 \mathrm{Ci} / \mathrm{gal}$. This is comparable to the wash water of tank 21 as discussed in Note 10, below. The large quantity of liquid required to alarm the VAMP would be observable to personnel thus no additional VAMP installations are deemed necessary.

8. The pump at this location is not operable, thus no additional monitoring is justified. Slurry Pumps will not be operated until a improved top seal and secondary containment is installed.

9. Although the operational sketches indicate a Slurry Pump at this location, no Slurry Pump is installed on this tank, thus no additional monitoring is justified.

10. A review of a potential spill involving components at Tank 21 or 22 indicated that a significant quantity of liquid would have to be present before endangering personnel. A spill of approximately 75 gallons of tank 21 wash water $($ Cs-137 = 
3.040 E-02 Ci/gal) would be required to alarm a VAMP at 50 feet. Since the source term associated with Tank 22 is smaller (Cs-137 $=2.5 \mathrm{E}-03 \mathrm{uCi} / \mathrm{L}$ ) than that of Tank 21, an even larger spill is required (Ref. $6 \& 7$ ). A spill of this nature would be apparent to personnel and one would not be expected to linger at the spill site. Therefore, it is concluded that additional VAMP installations are not required at Tanks 21 and 22 for personnel protection.

11. The Catch Tank contents are reasonably clean water per Section 3.3.4.3 of Ref. 9. Therefore, no additional monitoring is required for personnel protection at the Catch Tank Gang Valves. 
WSRC-TR-95.

January 3, 1995

Page 11 of 11 GRAPH 1

\section{Dose Rate Versus Distance From a 0.06 Gallon Spill of High Heat Supernate}

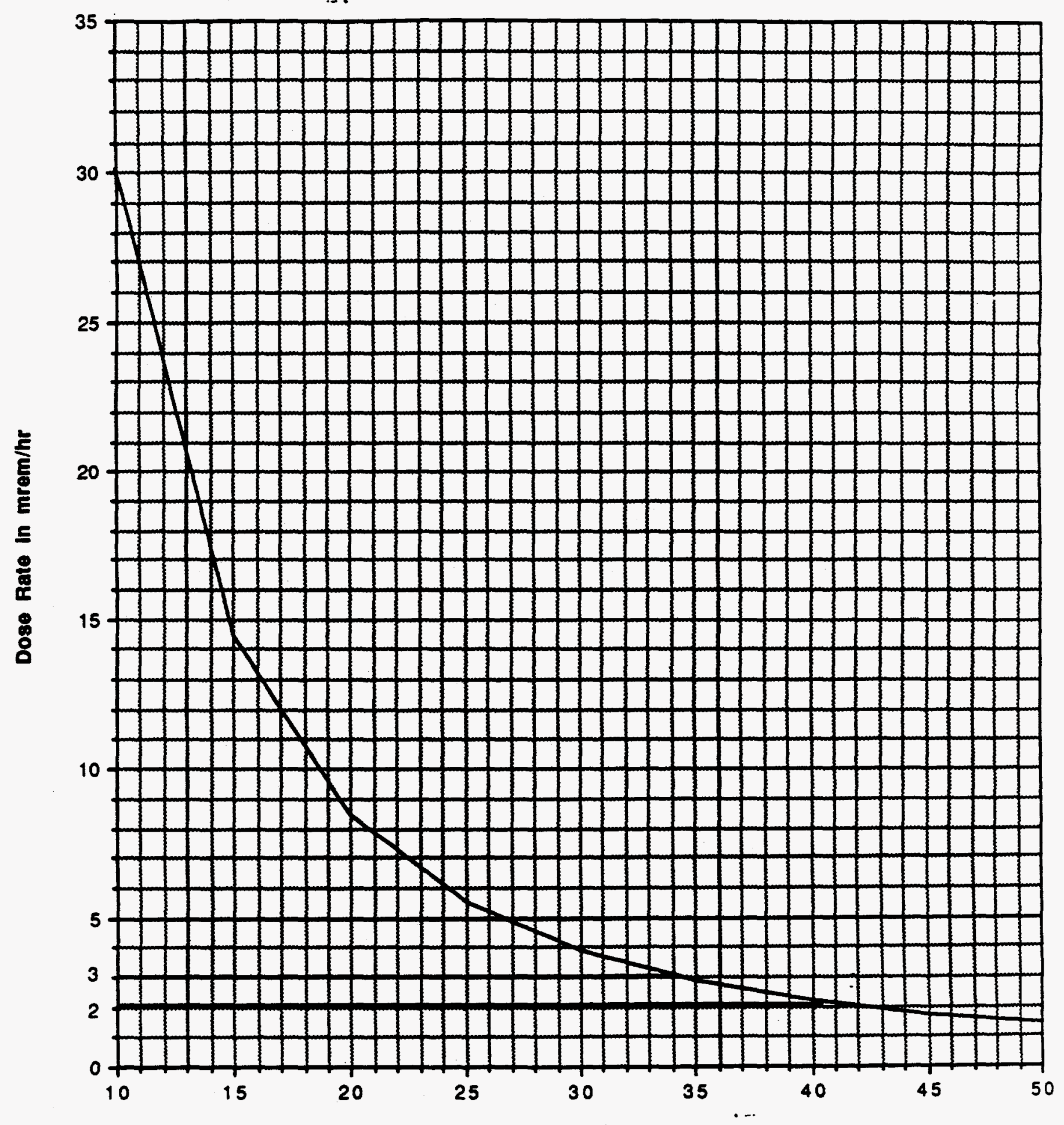

Figure is taken from Technical Support Group Calculation Number KHR0188. 


\section{ATTACHMENT TO \\ WSRC-TR-95-0004}

FIGURES 1 THROUGH 20

OF ESH-HPT-94-0154 
ESH-HPT-94-0154

Page 4

Figure 1

Area Radiation Monitor Locations H-Area Tank Farm Old Hill West Eng

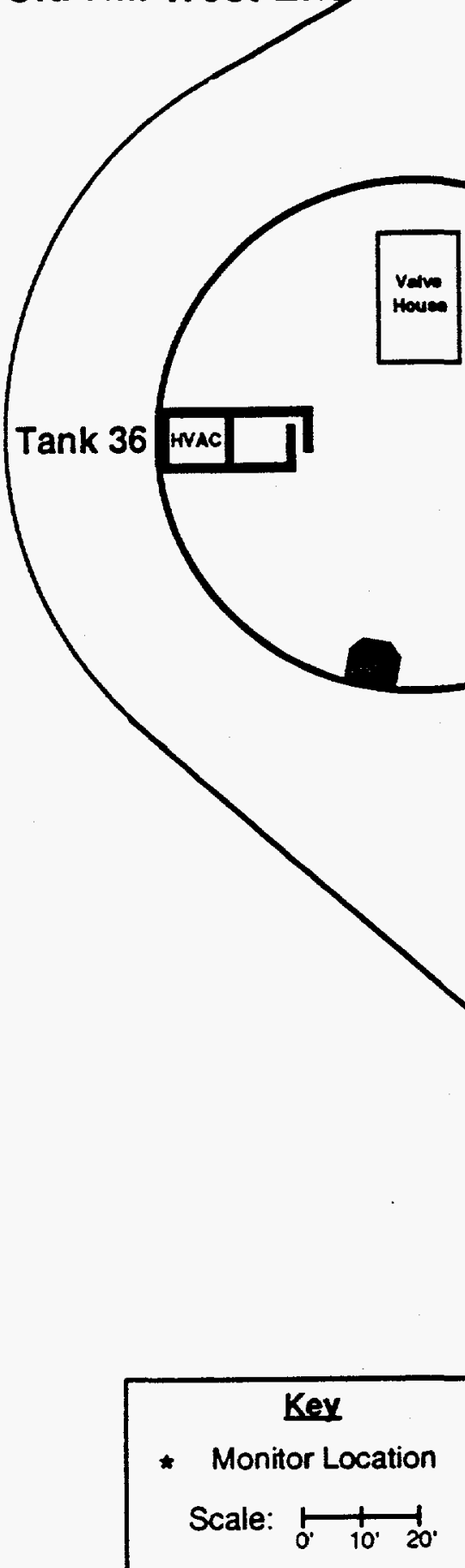

Tank 37
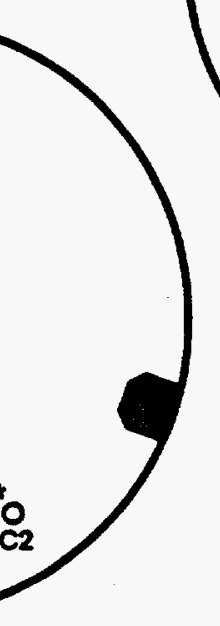


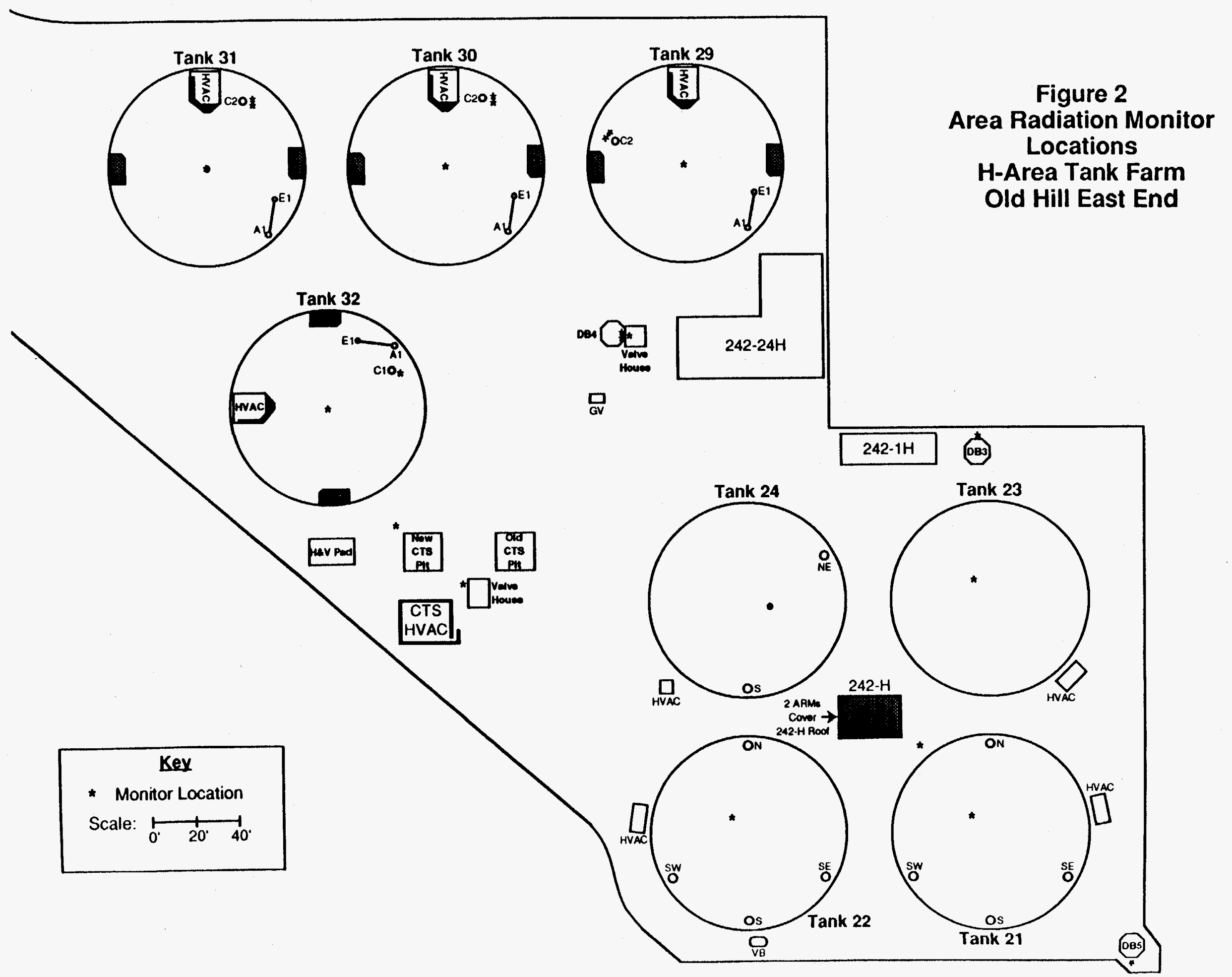


ESH-HPT-94-0154

Page 6

Figure 3

Area Radiation Monitor

Locations

H-Area Tank Farm

Type I and II Tanks
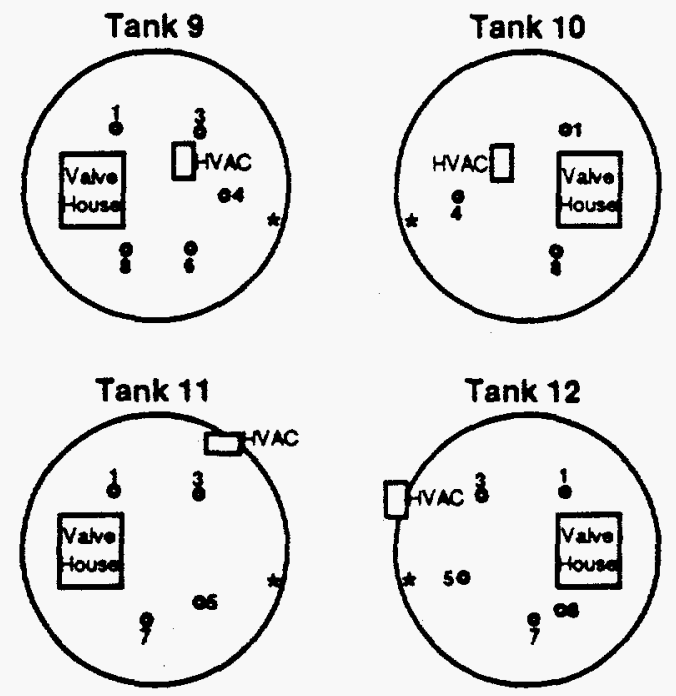

DB2 / Pump Pits 1-4

\section{Key}

- Monitor Location

Scale:

$\begin{array}{llll}0^{\prime} & 20^{\circ} & 40^{\circ} & 60^{\circ}\end{array}$

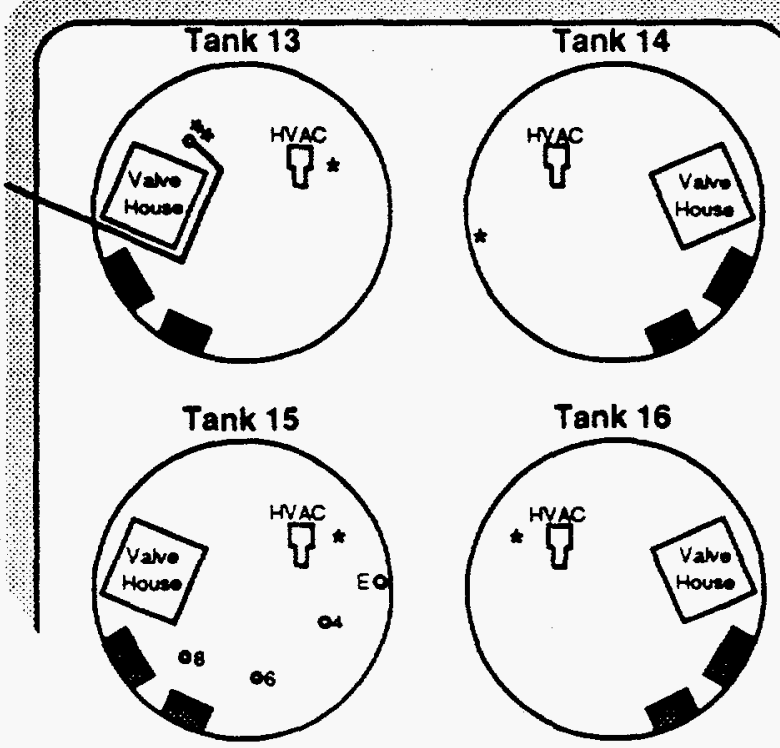


Figure 4

\section{Area Radiation Monitor Locations \\ H-Area Tank Farm \\ New Hill}
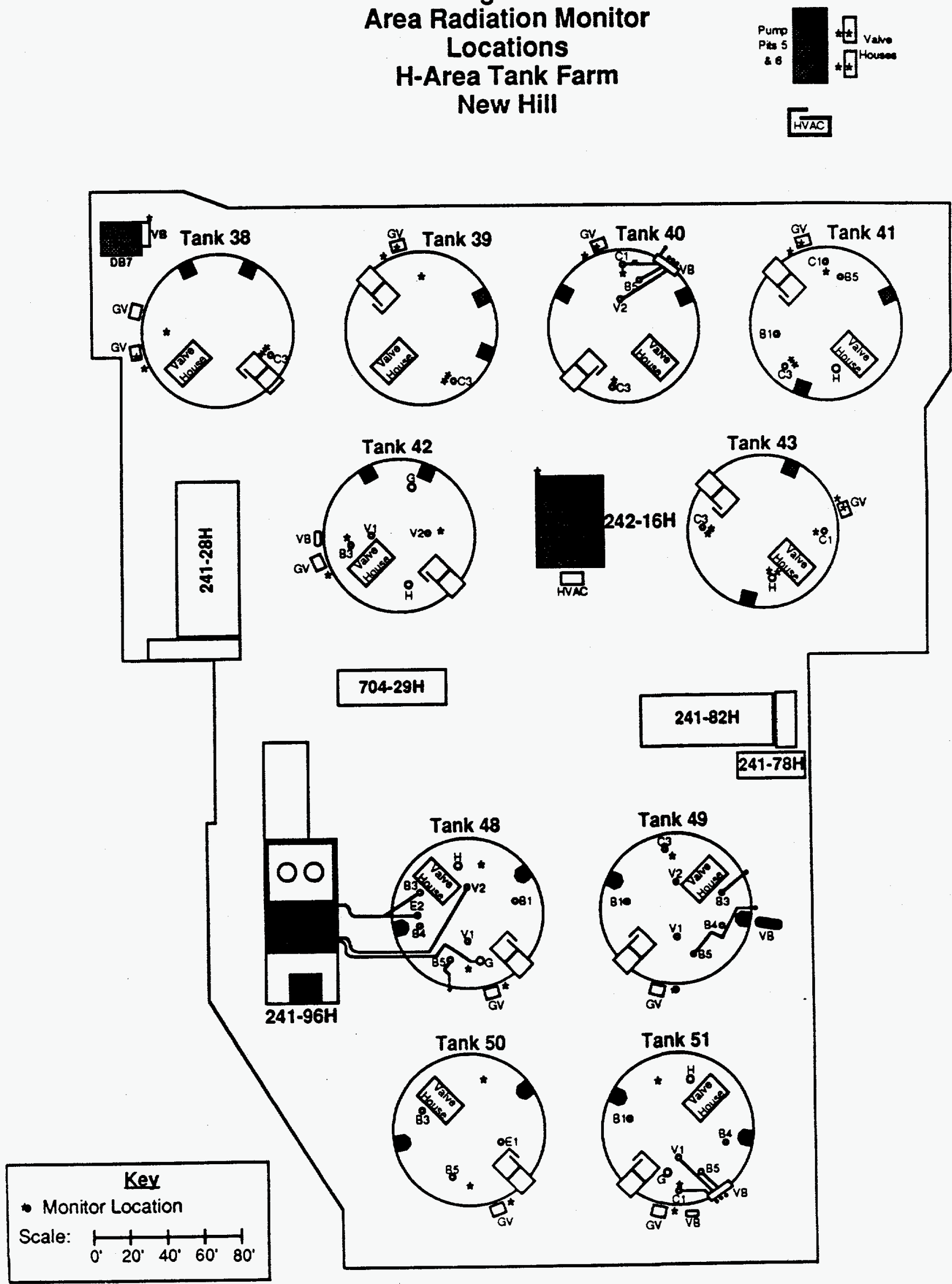
Figure 5

Area Radiation Monitor

Locations

H-Area Tank Farm

East and West Pump Houses
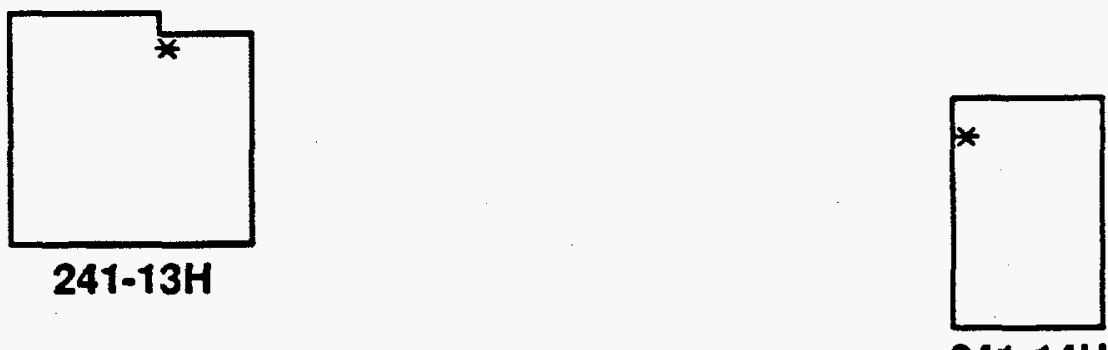

Key

* Monitor Location

Scale:

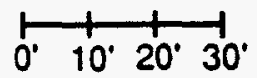


Figure 6 Area Radiation Monitor Locations

F-Area Tank Farm Northeast Corner
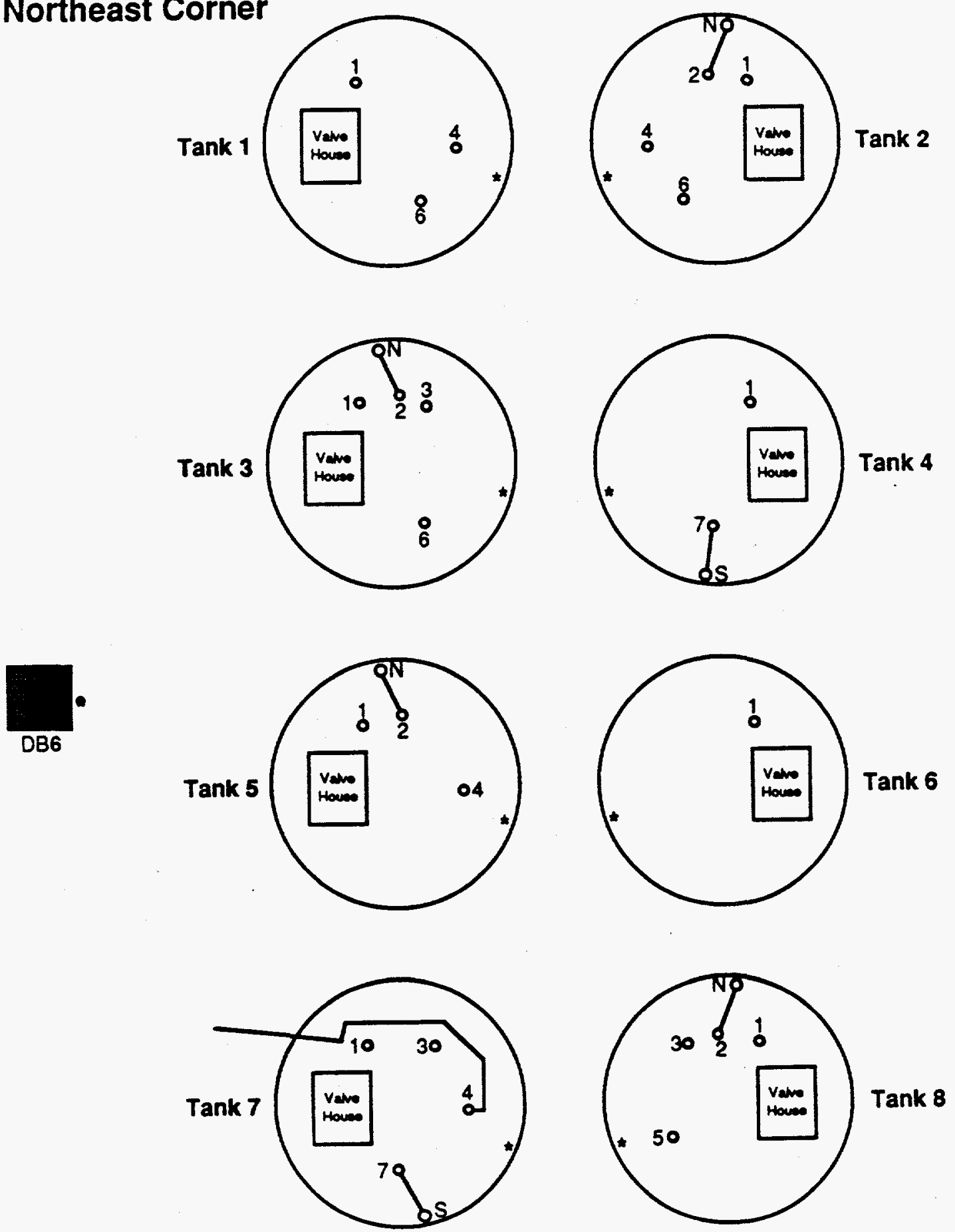

\section{Key}

- Monitor Location Scale: $\frac{1}{20^{\circ}} 4^{\circ} \quad 60^{\circ}$ 


\section{Locations}

F-Area Tank Farm

Southwest Corner
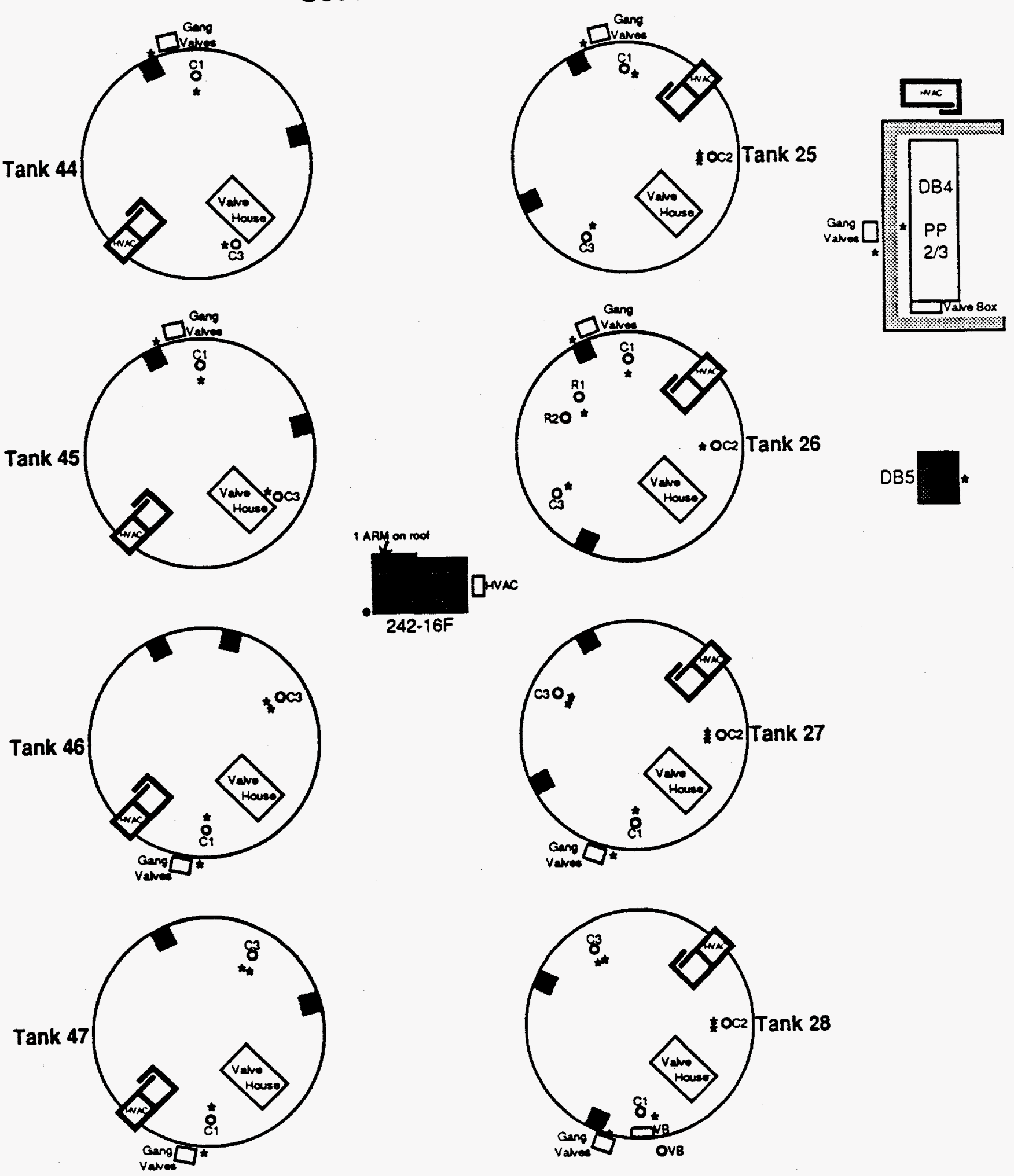

\section{Key}

* Monitor Location Scale: $\underbrace{1}_{20} \quad \frac{1}{\infty}$ 
Figure 8

Area Radiation Monitor

Locations

F-Area Tank Farm

Northwest Corner

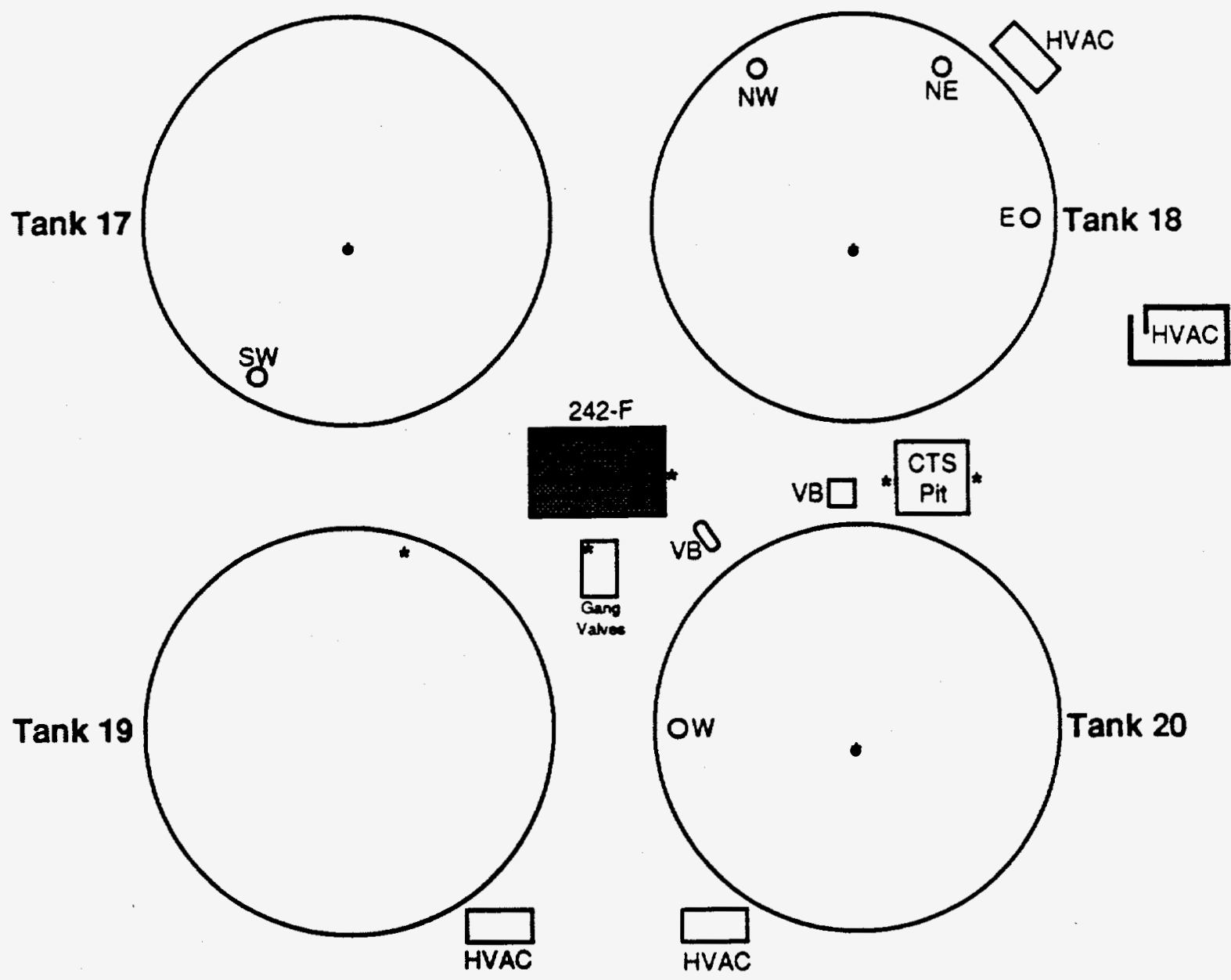

\section{Key}

- Monitor Location

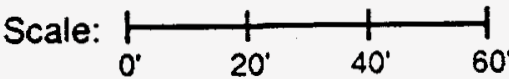


Figure 9

Area Radiation Monitor Locations

F-Area Tank Farm Southeast Corner

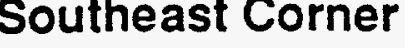

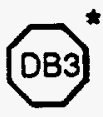
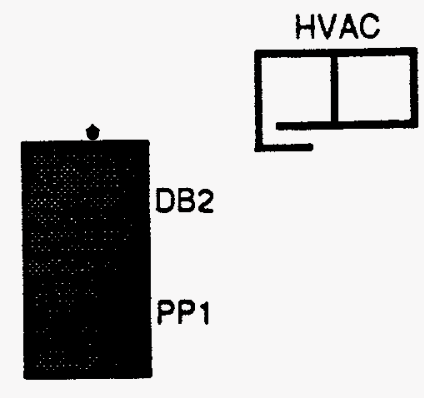

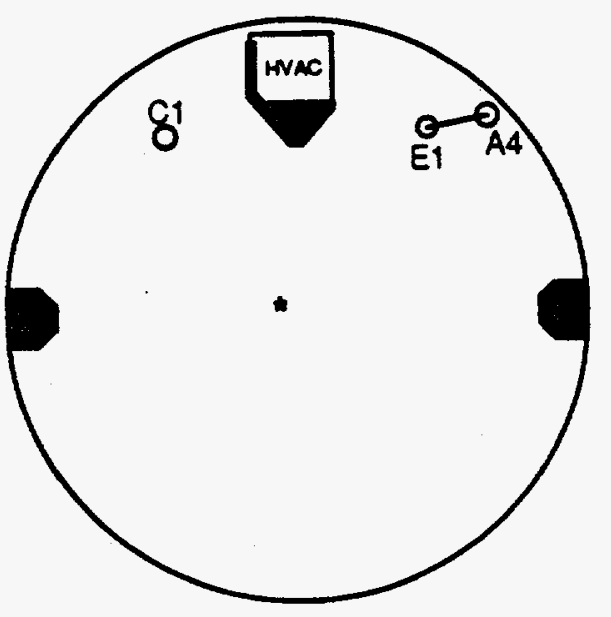

Tank 33

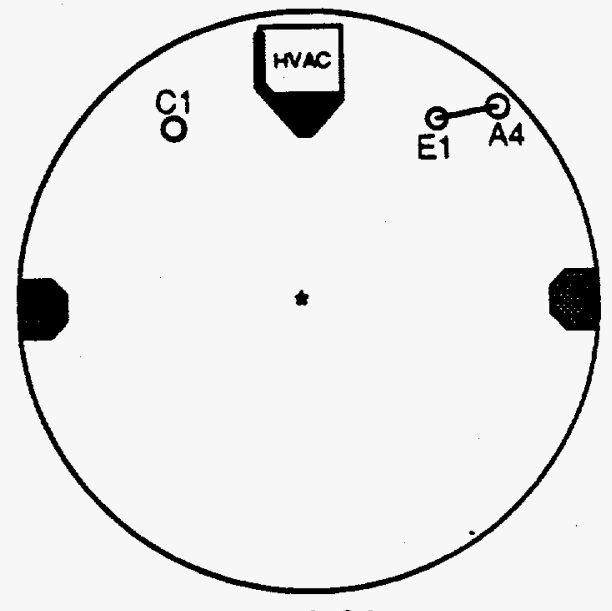

Tank 34

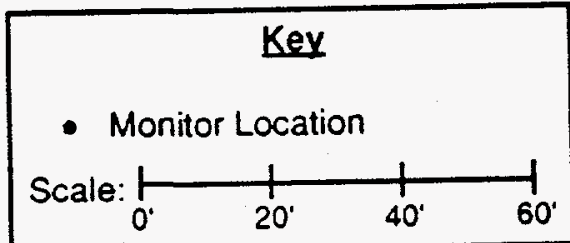




\section{Figure 10}

Area Radiation Monitor

Locations

\section{F-Area Tank Farm}

Pumphouses
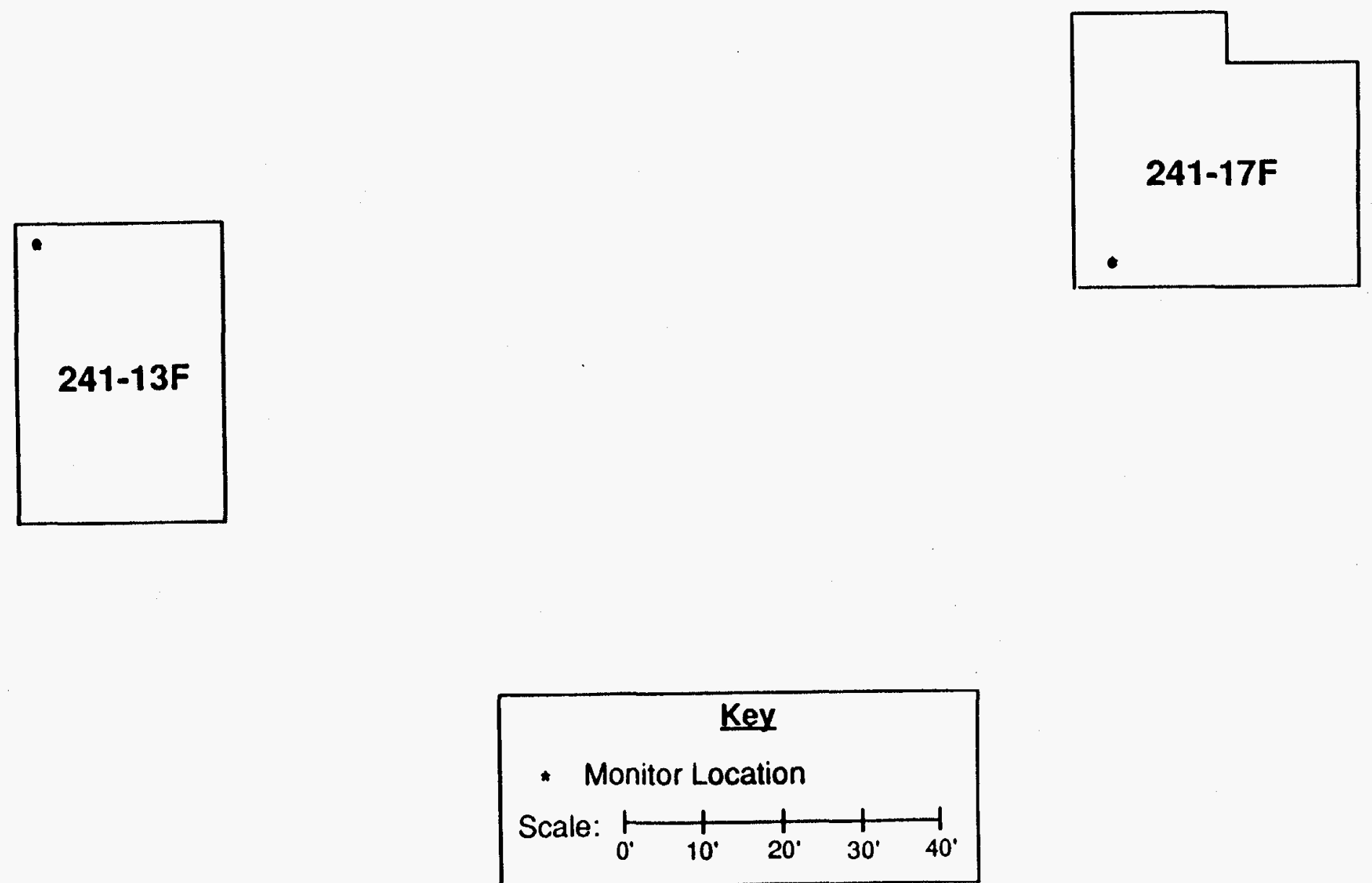
Area Radiation Monitor

Coverage Areas

H-Area Tank Farm

Old Hill West End

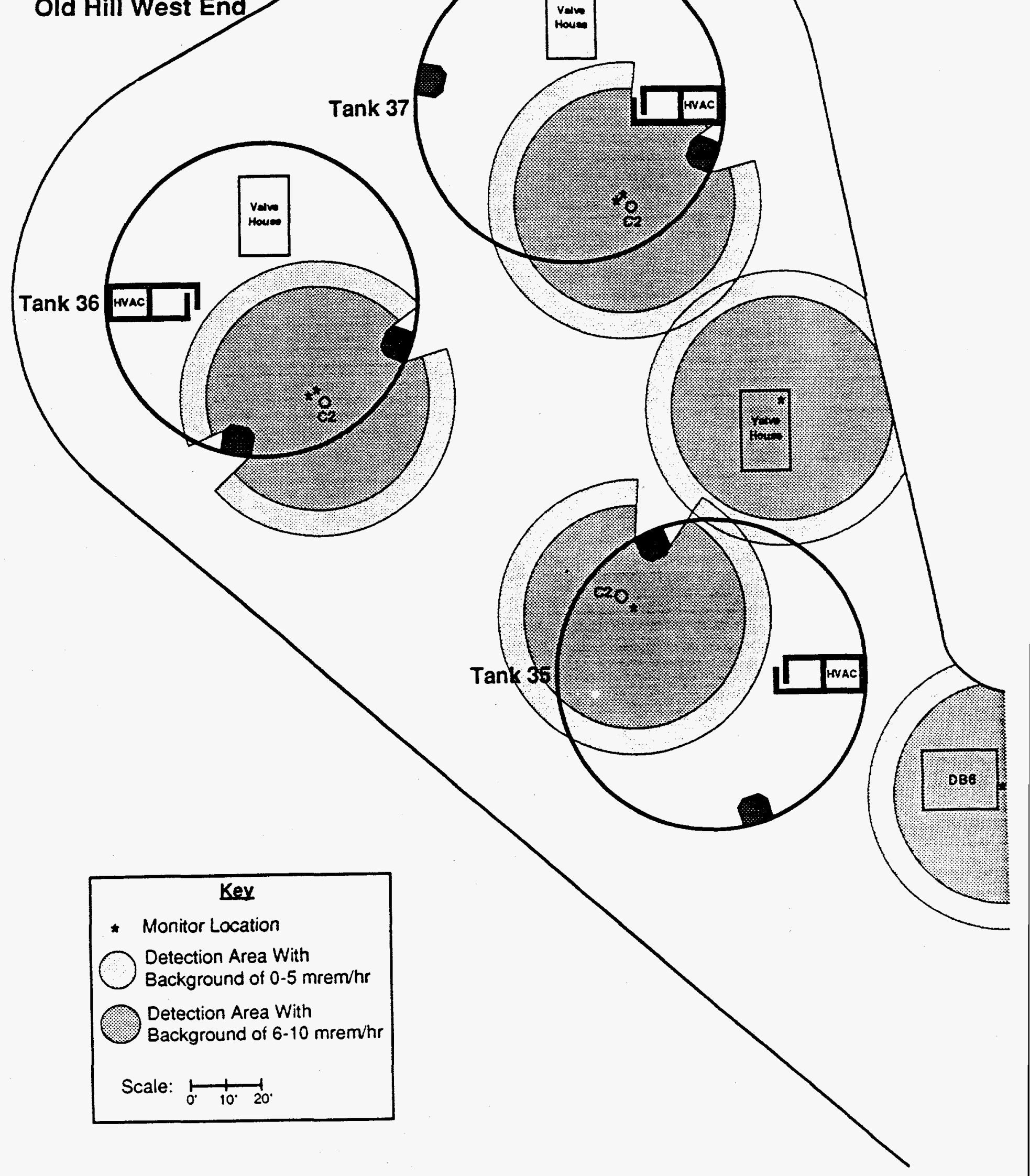




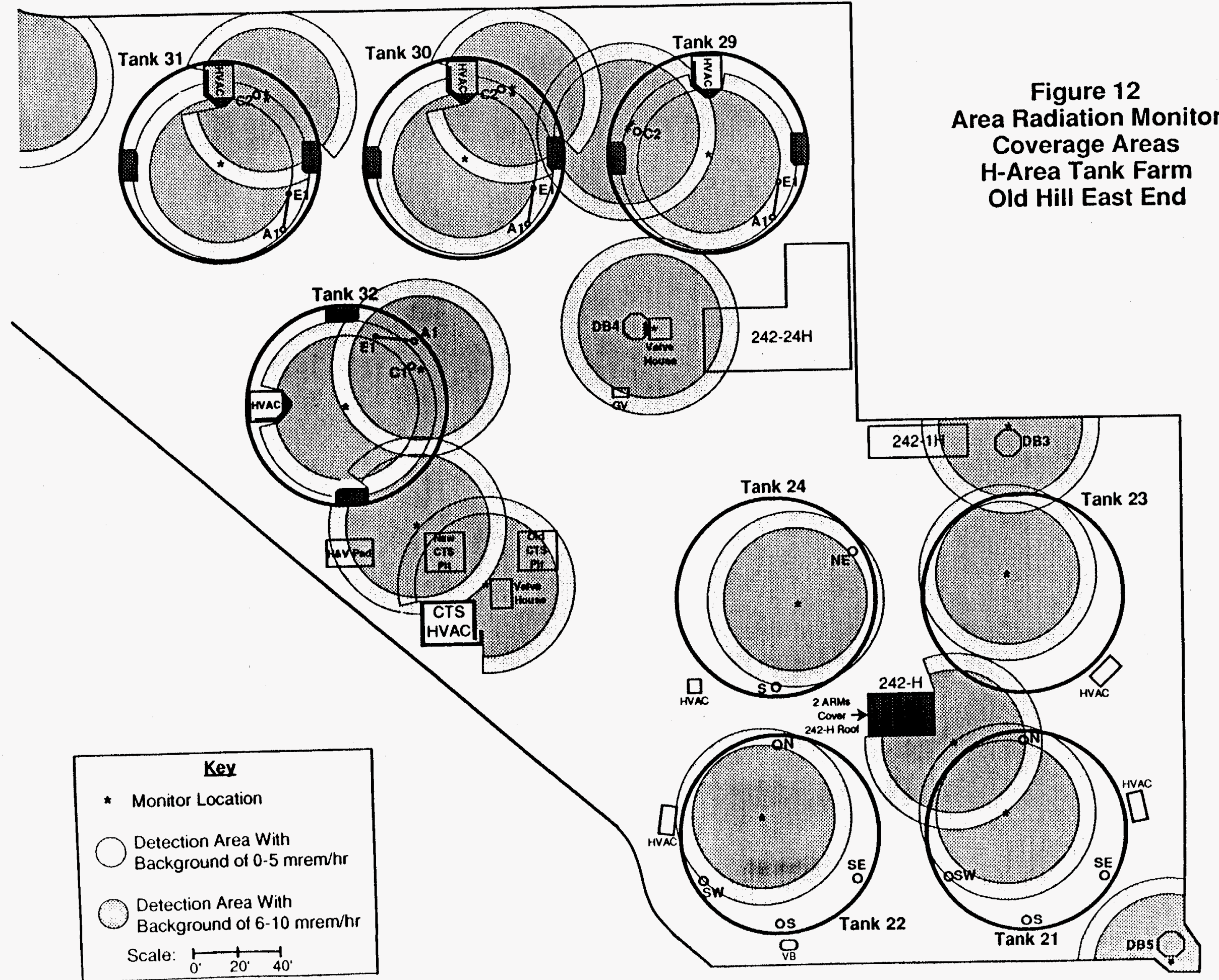


Figure 13

Area Radiation Monitor

Coverage Areas H-Area Tank Farm Type I and II Tanks
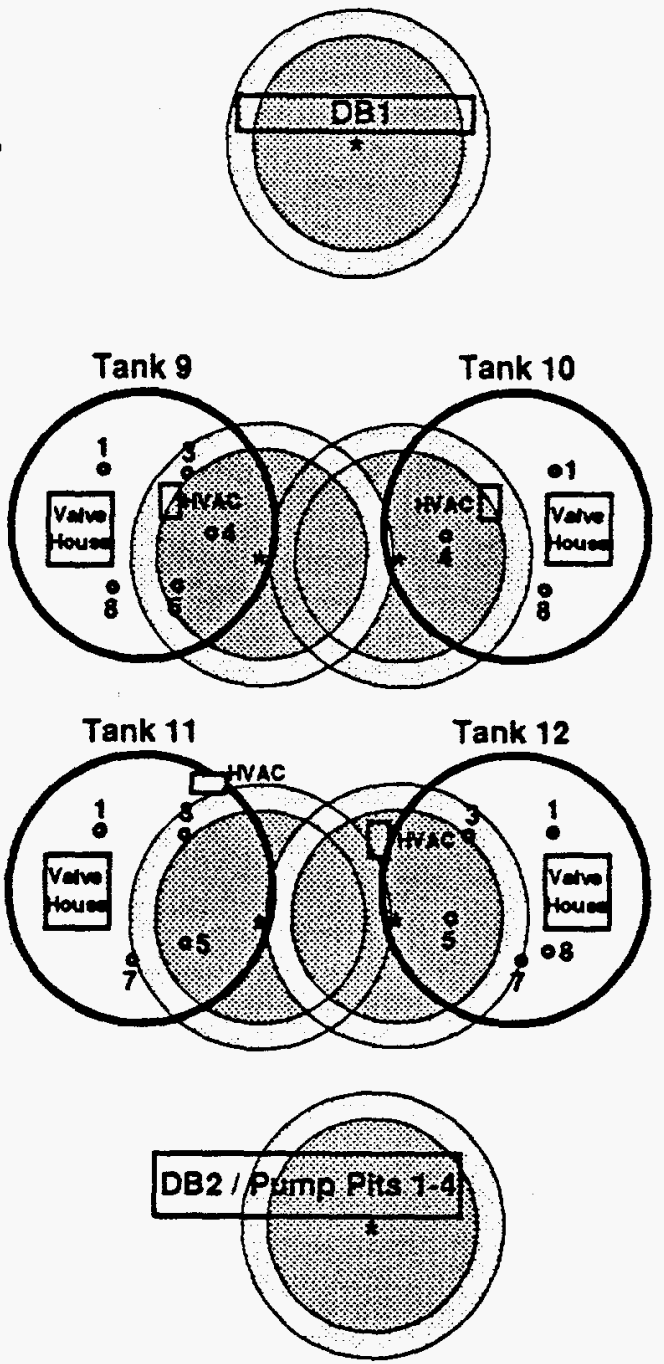

\section{Key}

- Monitor Location

Detection Area With

Background of $0.5 \mathrm{mrem} / \mathrm{hr}$

Detection Area With

Background of 6-10 mrem/hr

Detection Area With

Background of $11-20 \mathrm{mrem} / \mathrm{hr}$

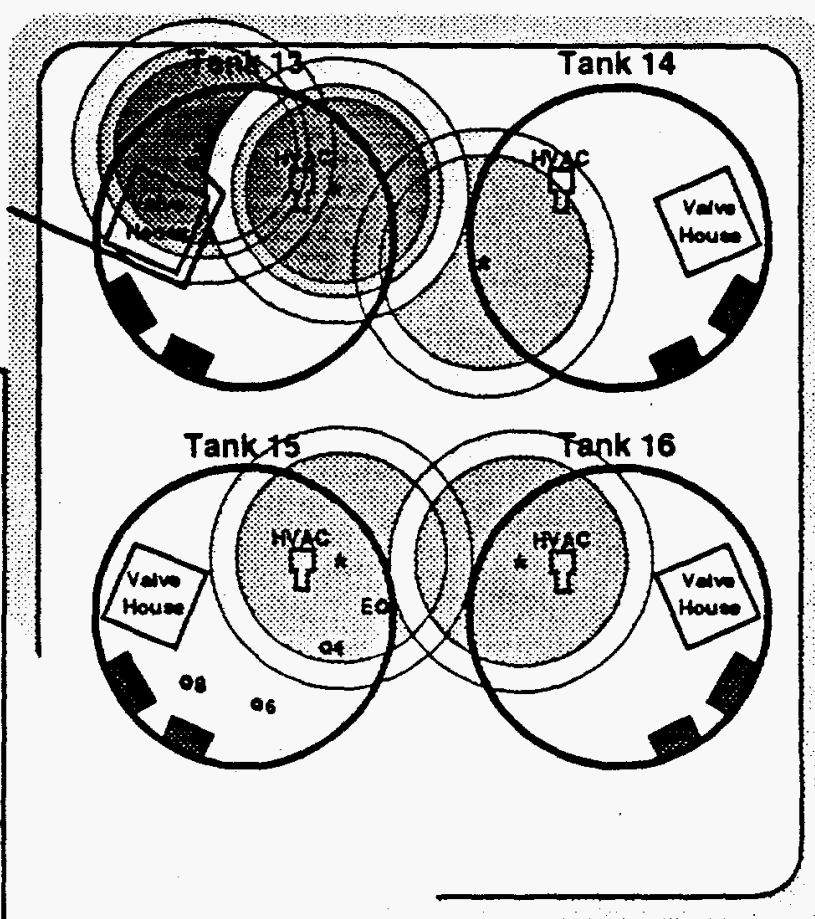

Scale:

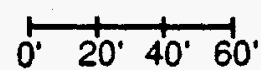




\section{Figure 14 Area Radiation Monitor Coverage Areas H-Area Tank Farm New Hill}
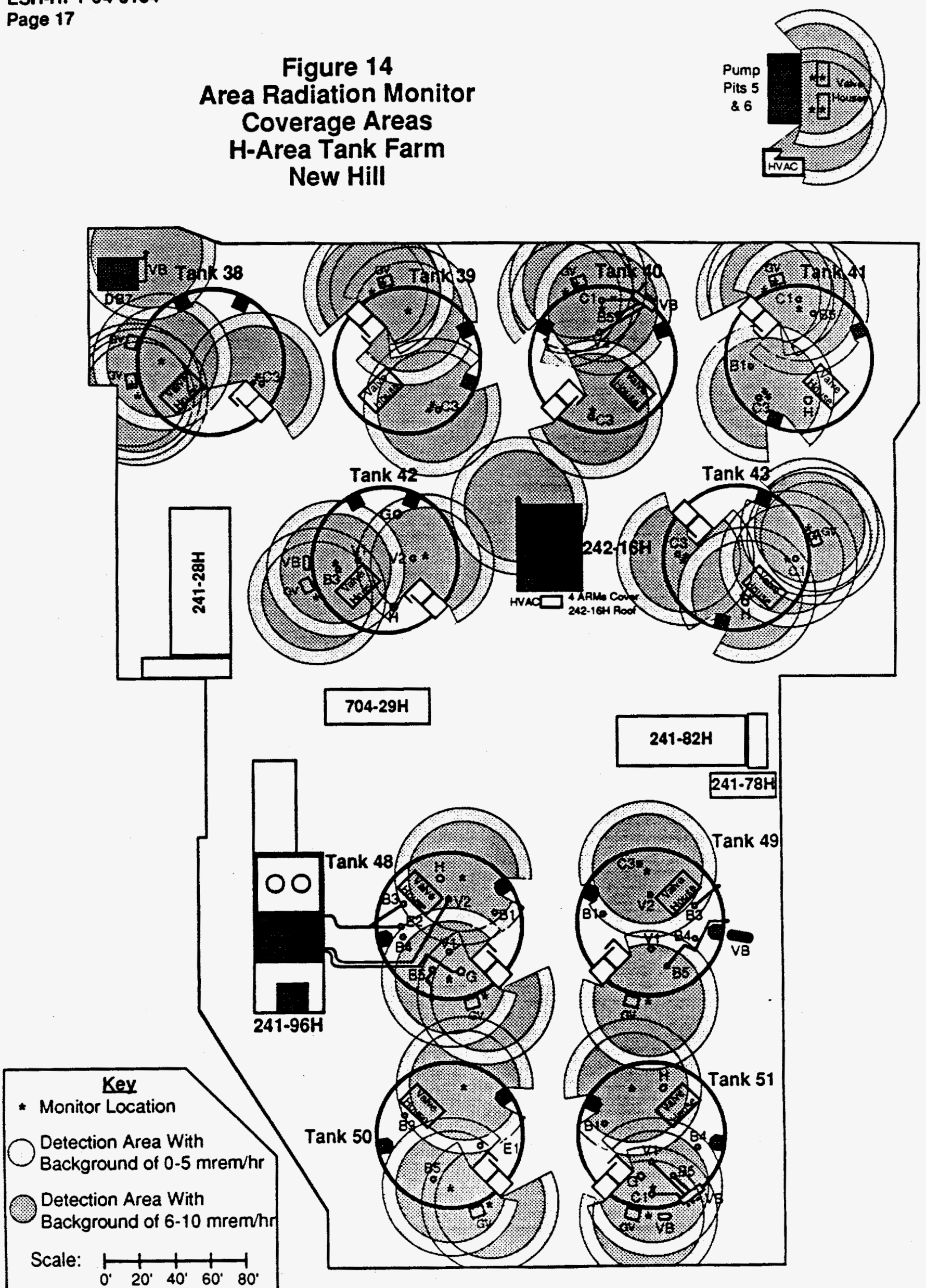
Figure 15

Area Radiation Monitoring

Coverage Areas

H-Area Tank Farm

East and West Pump Houses
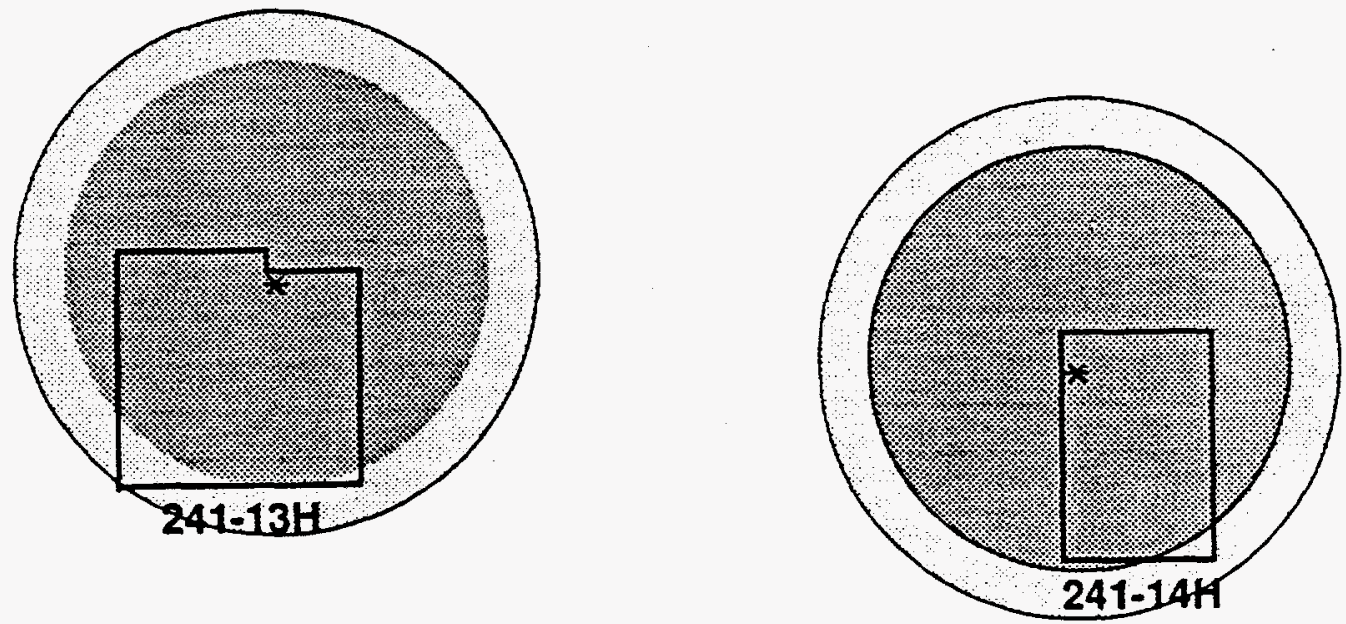

\section{Key}

* Monitor Location

Detection Area With

Background of $0.5 \mathrm{mrem} / \mathrm{hr}$

Detection Area With

Background of 6-10 mrem $/ \mathrm{hr}$

Scale:

$$
\stackrel{1}{0^{\circ}} 1^{\circ} 20^{\circ} 30^{\circ}
$$


Figure 16 Area Radiation Monitor Coverage Areas F-Area Tank Farm Northeast Corner

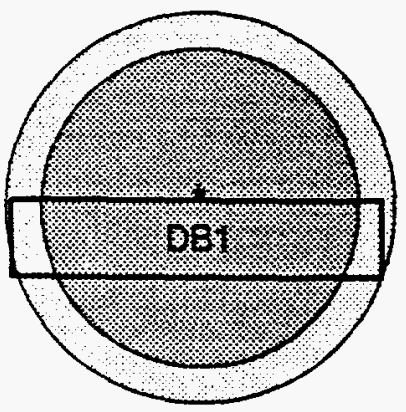

Tank 1
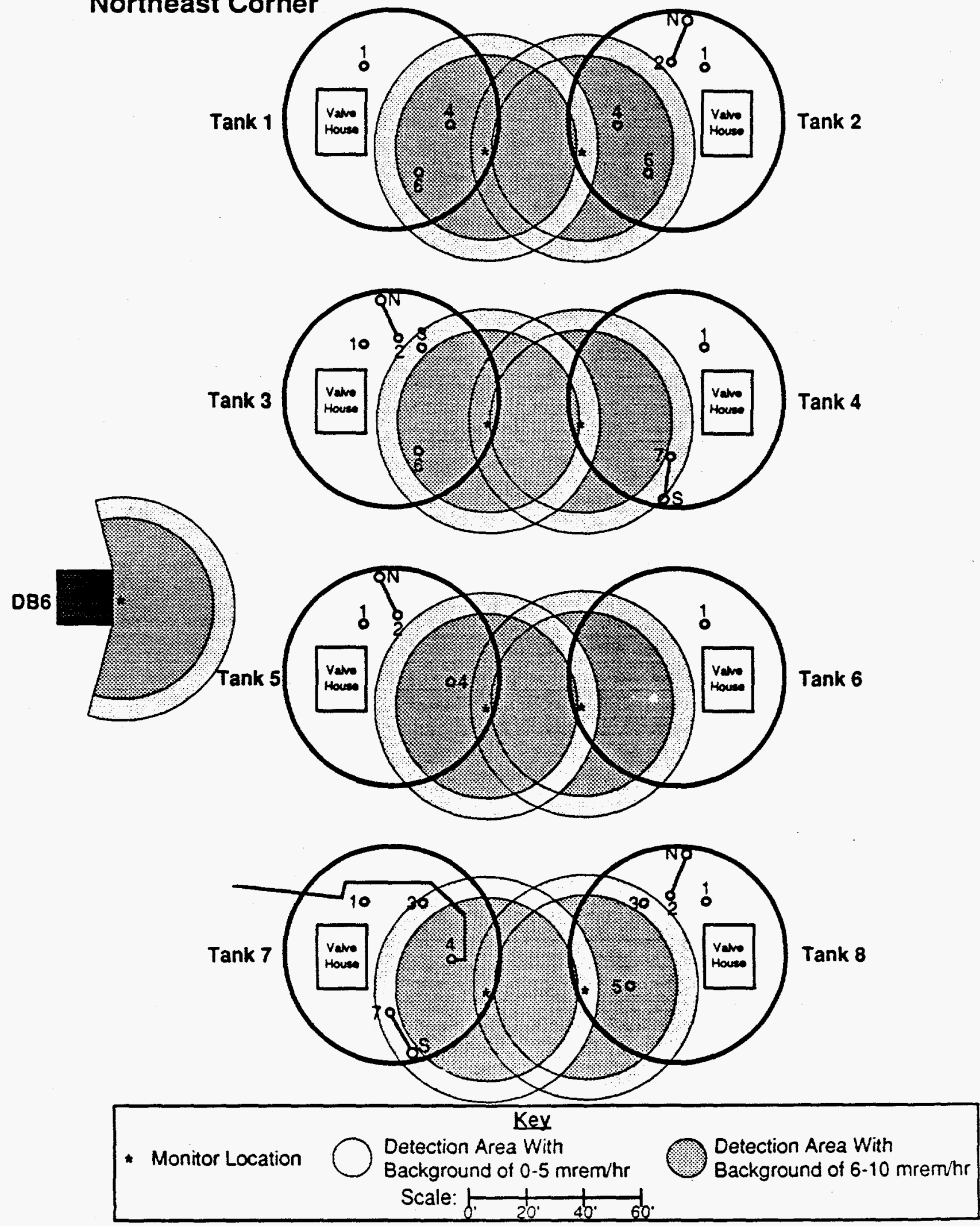
Figure 17 Area Radiation Monitor Coverage Areas

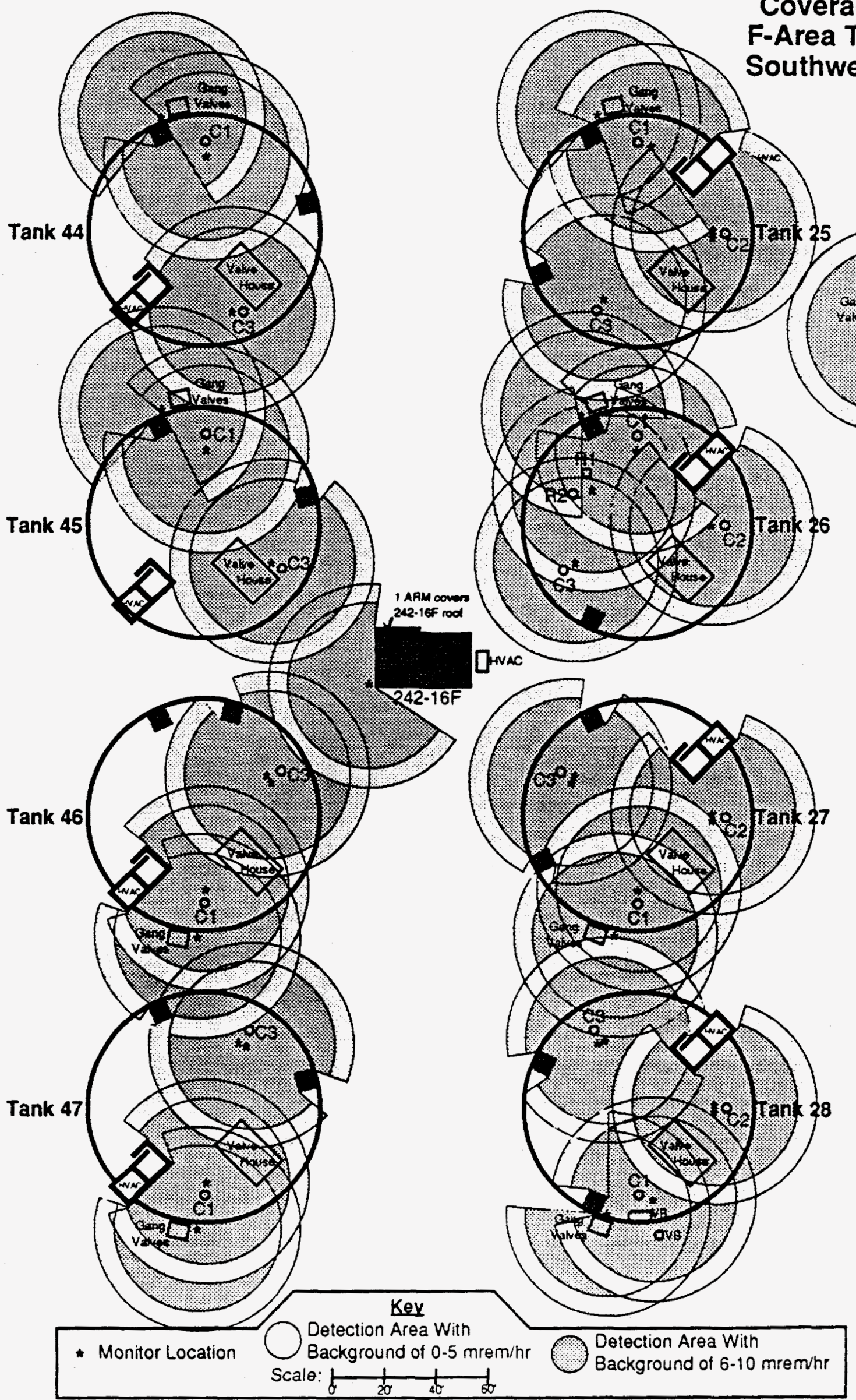


Figure 18

\section{Area Radiation Monitor \\ Coverage Areas \\ F-Area Tank Farm \\ Northwest Corner}

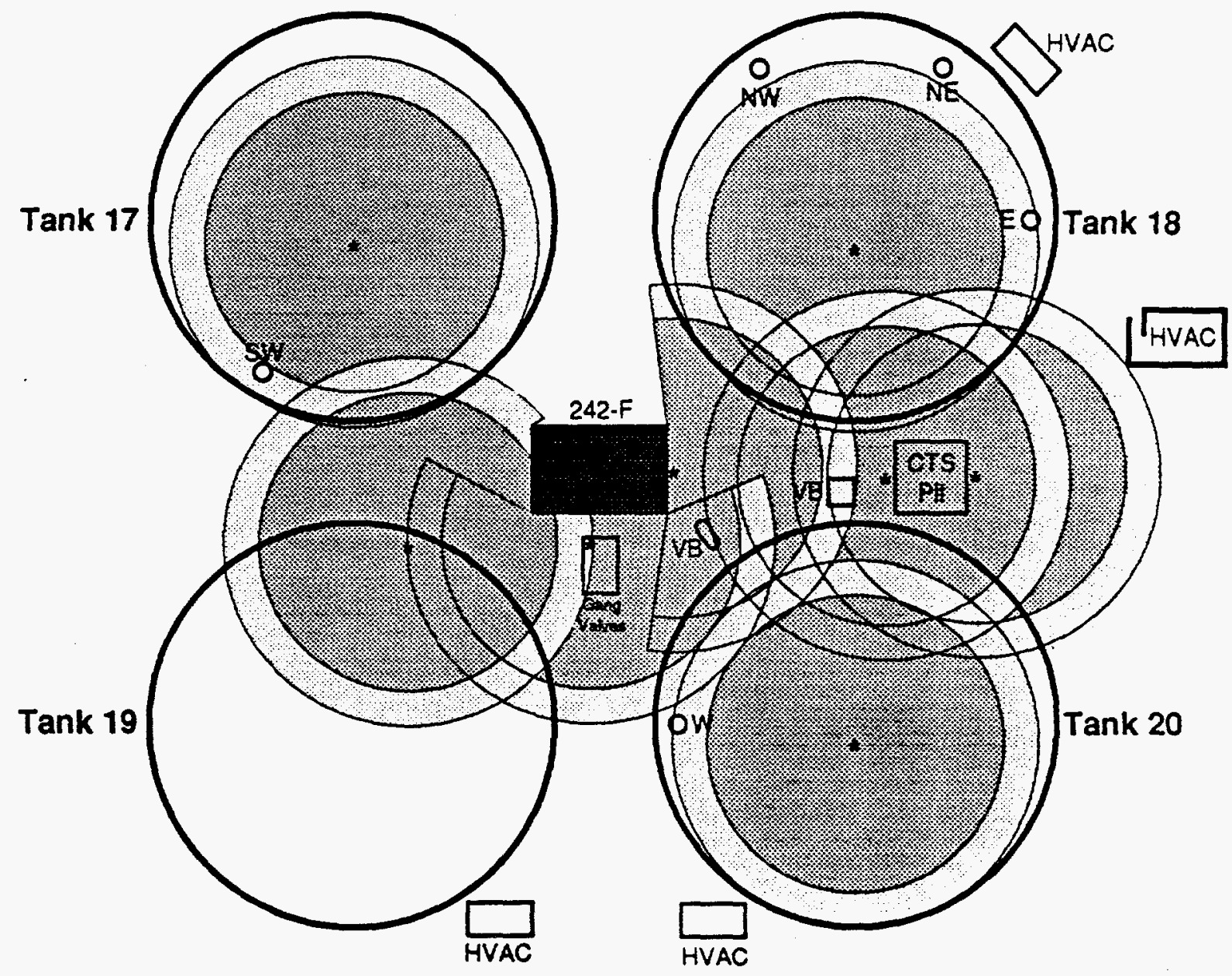

\section{Kex}

- Monitor Location

Detection Area With

Background of 0-5 mrem/hr

Detection Area With

Background of 6-10 mrem/hr

Scale: $\overbrace{0^{\circ}} \underbrace{}_{20^{\circ}} \quad 4^{\circ} \quad 60^{\circ}$ 


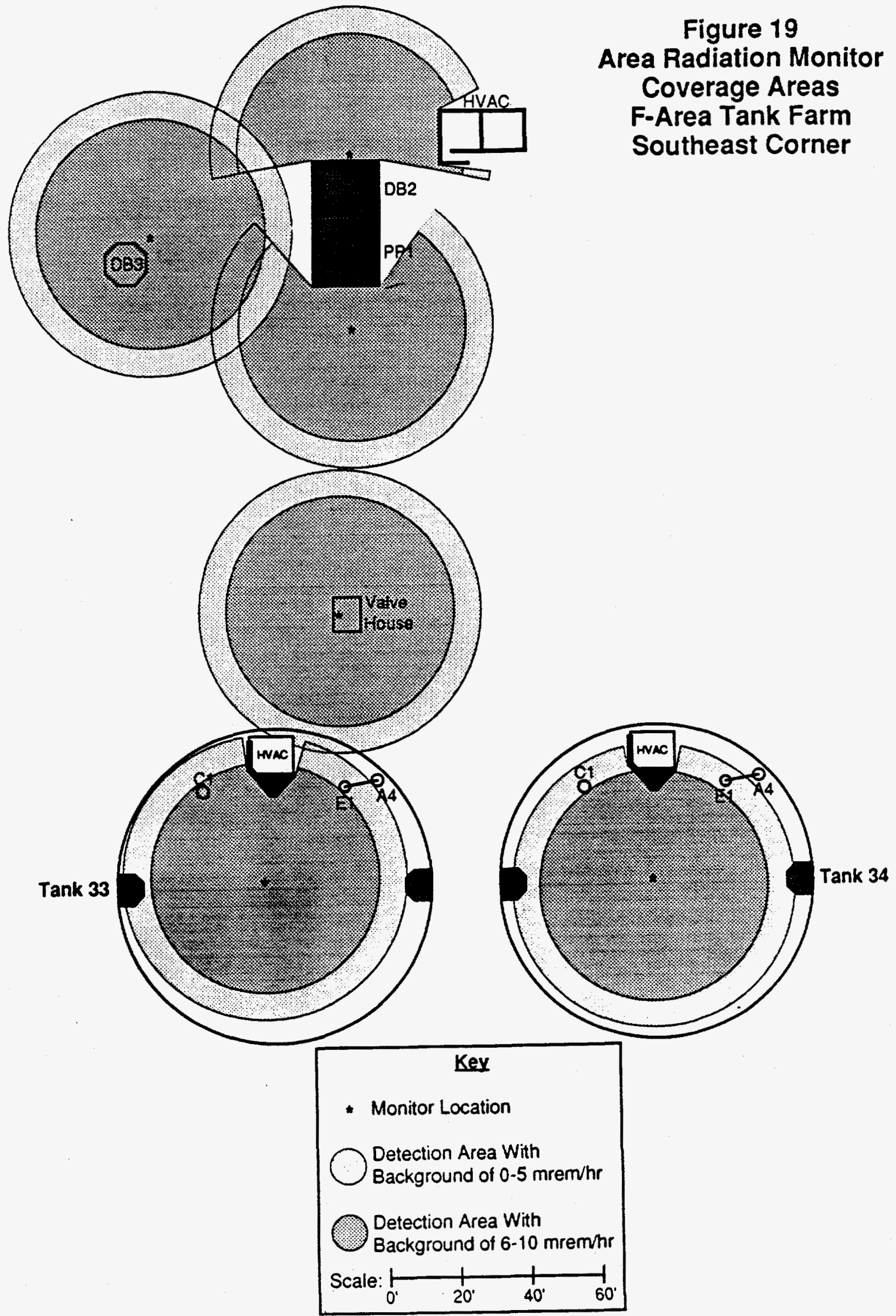


